\title{
SOME REFLECTIONS ON CUSTOM IN INTERNATIONAL ECONOMIC LAW
}

\author{
BARTOSZ ZIEMBLICKI*
}

\section{INTRODUCTION}

Custom as a source of law plays a much greater role in international law than it does in municipal law. However, with the huge development of treaty law over the last two centuries, its significance for international relations becomes less evident. International economic law is a part of international law in which it is even harder to present evidence of customary law. One possible explanation of this situation is that there is not much consensus on customary law in international economic law, because there is no consensus on the meaning of the term international economic law. It also may be that it only seems that there is not much customary international economic law, because there is not much scholar interest in this subject. Another explanation might be that custom simply does not play a significant role in international economic relations.

\section{The Problems WITH A DEFINITION OF INTERNATIONAL ECONOMIC LAW}

In order to determine whether there is customary international economic law one must establish what international economic law actually means. ${ }^{1}$ The main problem with the definition of international economic law is if it distinguishes from other branches of law based on the criterion of the sources of law or based on the criterion of the object of regulation. ${ }^{2}$ In the first view, international economic law would therefore include norms of public international law which regulate economic affairs. In the second view it would include norms which regulate international economic affairs,

DOI: $10.1515 /$ wrlae-2018-0042

* Assistant Professor, Wroclaw Economics University, bartosz.ziemblicki@ue.wroc.pl, ORCID: https://orcid.org/0000-0002-5814-5689.

${ }^{1}$ This issue has been discussed in more detail in B Ziemblicki, 'Współczesne rozumienie pojęcia międzynarodowego prawa gospodarczego’ (2014) 197(1) Studia Prawnicze PAN 181.

2 J Białocerkiewicz, Powstanie i rozwój prawa międzynarodowego gospodarczego (1987) 43-44. 
regardless of whether those norms are of international, municipal or other origin. It would also be irrelevant whether the norms belong to public law or private law. For example in Kenneth Abbott's opinion ${ }^{3}$ sources of international economic law include supranational (EU law), international, transnational and municipal regulations and even private rules such as the INCOTERMS. ${ }^{4}$ In Polish literature, over time this second view gains more and more scholarly support. ${ }^{5}$

When Georg Schwarzenberger wrote about international economic law 65 years ago, he did not define it simply as a part of public international law; however his description of this area of law was characteristic for relations between states. ${ }^{6}$ Similar views were expressed as late as at the beginning of the 1990 s by Judith Bello i Alan Holmer. ${ }^{7}$ Also Ignaz SeidlHohenveldern expressed the opinion that international economic law is a part of public international law. He mentions that if an economic aspect was to be understood broadly (indirectly), then international economic law would constitute, almost entirely, public international law $^{8}$. Surprisingly he did suggest future possibility of including lex mercatoria, which traditionally regulated relations between private actors ${ }^{9}$.

The above-named scholars are in a minority. Most scholars support the second, broader approach to international economic law. According to Stephen Zamora it is a set of rules and practice regulating economic relations between subjects from different states and also between different states themselves. It encompasses law and politics, in particular private law, local law, municipal law and international law. ${ }^{10}$ In Jeffery Atik's view it includes, at the least, international trade law, monetary law, competition (antimonopoly) law, intellectual property law and development law. ${ }^{11}$

To Trachtman, the creation of a legal order called international economic law is a revolution, because it leads to a more coherent view of the

\footnotetext{
${ }^{3}$ KW Abbott, 'International Economic Law: Implications for Scholarship' (1996) 17(2) University of Pennsylvania Journal of International Economic Law 505, 507-508.

${ }^{4}$ International Commercial Terms - set of rules issued by the International Chamber of Commerce, regulating sales and delivery of goods, commonly applied worldwide. First published in 1936, the most recent version in 2010.

5 E.g., T Wasilewski, 'Prawo międzynarodowe publiczne, międzynarodowe prawo gospodarcze a europejskie prawo wspólnotowe - aspekt komparatystyczny’ (2005) 3 Studia Europejskie 31, 35; K Lankosz, B Kuźniak, 'Stosunki międzynarodowe - przedmiot i metoda nauczania <http://www.pism.pl/pdf/K.Lankosz-B.Kuzniak.pdf> accessed 7 September 2015. ${ }^{6}$ G Schwarzenberger, 'The Province and Standards of International Economic Law' (1984) 2 International Law Quarterly 402, $402 \mathrm{ff}$.

7 JH Bello, AF Holmerz, 'After the Cold War: Whither International Economic Law?' (1991) 32(2) Harvard International Law Journal 323.

${ }^{8}$ I Seidl-Hohenveldern, International Economic Law (Hague, London, Boston 1999) 1. Also P VerLoren van Themaat, The Changing Structure of International Economic Law (Hague 1981) 9.

${ }^{9}$ I Seidl-Hohenveldern (n 8) 2.

${ }^{10}$ S Zamora, 'International Economic Law', (1996) 17(1) University of Pennsylvania Journal of International Economic Law 63, 63-64.

11 J Atik, 'Uncorking International Trade, filling the cup of International Economic Law' (1999-2000) 15 American Journal of International Law Review 1231, 1232.
} 
world. ${ }^{12}$ It is a breaking of the artificial borders between public and private, and also international and municipal law, leaving only one critical criterion the economic aspect of the law. To him these divisions only make sense for university teaching, but not for legal theory and practice. ${ }^{13}$

The understanding of international economic law as a functional conglomerate of legal norms from different legal orders is also supported by experts of international law such as John H. Jackson ${ }^{14}$ and Hans-Ulrich Petersmann ${ }^{15}$. The former additionally holds the opinion that as much as $90 \%$ of public international law is at the same time international economic law ${ }^{16}$ (an opinion similar to that of Ignaz Seidl-Hohenveldern). He also recognizes components of municipal law, and even the influence of other scientific disciplines such as political science and economics. ${ }^{17}$

According to Asif Qureshi and Andreas Ziegler, authors of the book International Economic Law, international economic law can be understood in two ways: narrower and broader. The narrower view limits it to a part of public international law. The broader includes all regulations pertaining to economic activity in an international context: municipal law, private international law and international business law. ${ }^{18}$ Supporters of the latter view emphasise that the definition should take into account the object of the regulation rather than the sources of law. ${ }^{19}$ Qureshi and Ziegler point out the differences between international economic law and public international law. ${ }^{20}$ These include the opposing assumptions of both systems. Public international law is based on the principles of sovereignty, economic selfsufficiency and mercantilism, while international economic law is based on comparative advantage, market economy and promotion of a global welfare. ${ }^{21}$

An interesting approach can be observed in Lowenfeld's writing. In the English legal literature, there are three books titled International Economic Law:22 one already mentioned by Asif Qureshi and Andreas Ziegler, another already mentioned by Seidl-Hohenveldern, and the third by

12 J Trachtman, 'The International Economic Law Revolution' <http://www.worldtradelaw.net/articles/trachtmanrevolution.pdf > accessed 7 September $2015,1,3$.

13 ibid 4.

14 JH Jackson, 'International Economic Law: Reflections on the "Boilerroom" of International Relations' (1995) 10 American University Journal of International Law and Policy 595, 596.

${ }^{15}$ E-U Petersmann, 'International Economic Theory and International Economic Law: On the Tasks of a Legal Theory of International Economic Order' in RStJ MacDonald, DM Johnston (eds) The Structure and Process of International Law: Essays in Legal Philosophy Doctrine and Theory (1983) 251.

16 Jackson (n 14) 596; similarly Abbott (n 3) 506.

${ }^{17}$ Jackson (n 14) 597-598.

${ }^{18}$ AH Qureshi, A Ziegler, International Economic Law (2011) 8.

19 See K Mortelmans, "The Interdependence of International, European and National Economic Law: The European Community Example' in PV Dijk, Restructuring the international economic order: the role for law and lawyers (1986) 14.

${ }^{20}$ Qureshi, Ziegler (n 18) 11.

21 DM McRae, 'The Contribution of International Trade Law to the Development of International Law' (1996) 1 Recueil des Cours de l'Academie de Droit International 99.

${ }^{22}$ Excluding those comprised of essays by different authors, such as e.g., CB Picker, ID Bunn, DW Arner (eds), International Economic Law. The State and Future of the Discipline (2008). 
Andreas Lowenfeld. Lowenfeld's book, published by the Oxford University Press $^{23}$ is enormous (ca. 950 pages). But when it comes to the definition of international economic law, the author does not present one. Furthermore he doesn't describe its sources or its subjects. From its content one can deduce that it includes mainly international trade law, and also international investment law and international monetary law. The preface informs us that it includes a wide range of matters: trade law, investment law, monetary law, dispute settlement, sanctions, individual and group actions, public international law and private international law. ${ }^{24}$

In Polish legal literature Janusz Gilas emphasised the meaning of public international law as an origin for shaping international economic law ${ }^{25}$, however he acknowledges that it includes norms of private law. ${ }^{26}$ Kazimierz Lankosz expressed a general view that international economic law is a separate branch of law and that it has an interdisciplinary character. ${ }^{27}$ Tadeusz Wasilewski argues against the recognition of international economic law as a part of public international law. ${ }^{28}$ Similarly to Qureshi and Ziegler he holds that the principle of international economic law is free trade, while the principle of public international law is sovereignty and the protection of internal interests. ${ }^{29}$ This protection from the standpoint of international trade law may be considered as protectionism, originally justified by the doctrine of economic sovereignty. ${ }^{30}$

The above examples are definitely not exhaustive. It seems, however, that international economic law include norms which fulfil the following criteria: first they are law (even if understood broadly, including soft-law); second they regulate international relations, even if formally they belong to municipal law; third they regulate economic activity.

\section{IMPACT OF CUSTOM ON INTERNATIONAL ECONOMIC LAW}

As already mentioned there are three books titled International Economic Law. It is natural to start searching for scholars' views on custom in international economic law there.

Ignaz Seidl-Hohenveldern does not pay much attention to custom in international economic law. He discusses this source of law in literally five lines in his book. He gives only two examples. One pertains to the claims of the Third World States that some UN General Assembly resolutions are in fact binding, because they constitute customary law. The second customary

\footnotetext{
${ }^{23}$ AF Lowenfeld, International Economic Law (2008).

${ }^{24}$ Lowenfeld (n 23) preface vii.

25 J Gilas, Prawo międzynarodowe gospodarcze (1998) 11.

${ }^{26}$ Gilas (n 25) 13.

${ }^{27}$ Lankosz, Kuźniak (n 5) 8.

${ }^{28}$ T Wasilewski, Stosunek wzajemny: porządek międzynarodowy, prawo międzynarodowe, europejskie prawo wspólnotowe, prawo krajowe (2004) $88 \mathrm{ff}$.

${ }^{29}$ Wasilewski (n 5) 32.

${ }^{30}$ G Schwarzenberger, The Principles and Standards of International Economic Law, (1966)

117 Recueil des Cours 1, 27-33.
} 
aspect is whether international economic law are trade usages. ${ }^{31}$ SeidlHohenbeldern does not elaborate on that. However, when mentioning trade usages, he notes that they may not only generate lex mercatoria, but also may become rules of customary international law. It is a consequence of his approach to the definition of customary international economic law, which includes only law between states and constitutes a part of public international law.

In Asif H. Qureshi's and Andreas Ziegler's view, the impact of custom on international economic law is marginal. Examples are: expropriation, international economic torts, economic warfare, interference with the international monetary system and the requirement to consult and collaborate in international monetary matters. They note that state practice has been driven by economically powerful states and also by international economic organizations. Similarly to Seidl-Hohenveldern, they also mention the problem with the nature of the UN General Assembly resolutions; however, they emphasise that there is lack of consensus between developing and developed states as well as academics on this issue. The same seems to be true for bilateral double taxation agreements and bilateral investment agreements. Finally, Qureshi and Ziegler acknowledge the influence of general customary international law on international economic relations, in particular the freedom of high seas, diplomatic protection, international claims, pacta sunt servanda, treatment of aliens and freedom of communication. ${ }^{32}$

The UN General Assembly resolutions mentioned by both Hohenveldern and Quershi and Ziegler refer to the so called New International Economic Order. The developing states called for it the 1970s, so that the law would not excessively favour wealthy states. As a consequence several guidelines and codes of conduct have been adopted. ${ }^{33}$ Of importance here is the Declaration on the Establishment of a New International Economic Order $^{34}$, but there are also the UN Charter of Economic Rights and Duties of States $^{35}$ and the Declaration on Permanent Sovereignty over Natural Resources. ${ }^{36}$ These resolutions provide for the entitlement of the developing countries to regulate and control the activities of multinational corporations operating within their territory, to nationalize or expropriate foreign property on conditions favourable to them, and to set up associations of primary commodities producers similar to the OPEC. All other States must recognize this right and refrain from taking economic, military, or political measures calculated to restrict it. Also international trade should be based on the need to ensure stable, equitable, and remunerative prices for raw materials, generalized non-reciprocal and non-discriminatory tariff preferences, as well as transfer of technology to developing countries; and should provide

\footnotetext{
${ }^{31}$ Seidl-Hohenveldern (n 8) 33-34.

${ }^{32}$ Qureshi, Ziegler (n18) 30.

${ }^{33}$ ME Ellis, 'The New International Economic Order and General Assembly Resolutions: the Debate over the Legal Effects of General Assembly Resolution Revisited' (1985) 15 California Western International Law Journal 647, 647-704.

${ }^{34}$ Declaration on the Establishment of a New International Economic Order, UNGA Res 3201 (S-VI) (1 May 1974).

${ }^{35}$ Charter of Economic Rights and Duties of States, UNGA Res 3281 (XXIX) (12 Dec 1974).

${ }^{36}$ Permanent sovereignty over natural resources, UNGA Res 1803 (XVII) (14 Dec 1962).
} 
economic and technical assistance without any strings attached. In the view of the developing states, these provisions confirm the existing customary law, while according to the developed states they do not.

Finally Lowenfeld in his book pays similarly little attention to custom in international economic law, as he does to the definition, sources and subjects of this area of law, which is none. ${ }^{37}$

The most systemic research of custom in international economic law so far was undertaken by Stephen Zamora a long time ago. ${ }^{38}$ His views also seem to be accurate nowadays. Zamora identified two major changes in the international economic order since the 1970s. These are the dispersal of economic power between more actors than just the United States and the increase of economic interdependence through industries such as banking, capital markets, the manufacturing process and communications. ${ }^{39}$ It seems that those tendencies even increased in the recent decades.

Zamora notes, that international economic organizations such as the IMF, the World Bank and the GATT (now the World Trade Organization) were so successful in shaping international economic relations that we got used to the fact that it is the treaty-based norms that constitute international economic law. Moreover, the increased economic interdependency, higher stakes and the increase in the number of actors contribute to the fact that nowadays it is much more difficult to achieve consensus and adopt new economic agreements than it was before. ${ }^{40}$ For these and other reasons custom has historically been ignored in analyses of the sources of international economic law ${ }^{41}$, but also international economic law has been ignored in analyses of customary international law. ${ }^{42}$

International economic law is dominated by treaty law. ${ }^{43}$ Some experts believe that it is the much developed treaty law that left no room for custom in international economic law. ${ }^{44}$ But on the other hand one could expect that the large increase in international economic transactions would give rise to customs. As Zamora stated, there is no theoretical reason why customary international economic law should not exist. ${ }^{45}$ Yet there are few examples of custom in this area of law.

Zamora strongly supports the view that international economic law is both public and private. According to him, the earliest form of this area of law was lex mercatoria, which first applied to merchants and only later was incorporated into national laws. To Zamora contemporary lex mercatoria is customary international law regulating international business transactions. ${ }^{46}$

\footnotetext{
${ }^{37}$ Lowenfeld (n 23).

38 S Zamora, 'Is There Customary International Economic Law?' (1989) 32 German Yearbook of International Law 9.

${ }^{39}$ Zamora (n 38) 9.

40 Zamora (n 38) 10.

${ }^{41}$ E.g., ME Villiger, Customary International Law and Treaties (1985).

${ }^{42}$ VeLoren van Themaat (n 8) 9; Schwarzenberger (n 30) 12.

${ }^{43}$ Schwarzenberger (n 30) 12.

${ }^{44}$ American Law Institute, 2 Restatement (Third) of the Foreign Relations Law of the United States (1987) 261.

${ }^{45}$ Zamora (n 38) 22.

${ }^{46}$ Zamora (n 38) 14-15.
} 
According to Zamora the most commonly accepted custom in international economic law is the expropriation of foreign-owned-property. Examples of this view can be found in international arbitration awards ${ }^{47}$ and also in UN General Assembly resolutions. ${ }^{48}$ What is problematic though is whether (just) compensation for expropriation is also a custom ${ }^{49}$.

In his opinion there is no such custom as freedom of commerce. ${ }^{50}$ States may remove barriers to international trade, if they wish to, but are not required to do so by any customary norm. On the other hand, economic coercion is a recognized customary norm in international economic law. It is a legitimate and preferred alternative to armed coercion ${ }^{51}$ and cannot be considered as contrary to the duty of non-intervention..$^{52}$

Also the basic principle of international economic law - mostfavoured-nation (MFN) treatment - is not a customary law and may only bind states as a treaty law (e.g. World Trade Organization law). ${ }^{53}$ In other words states are free to discriminate.

A controversial issue is a duty to protect the monetary systems of other states. States generally do not have such an obligation; however, they should not intentionally disrupt the international monetary and banking system and should consult and collaborate with other states in solving transnational monetary problems. ${ }^{54}$ States must also definitely prevent and punish counterfeiting of a foreign state's currency. ${ }^{55}$

According to Zamora uncertainties regarding the status of customary international economic law also pertain to three other issues. First is the state immunity from the jurisdiction of another state in purely commercial activities. Second is the question of whether states are free to enact legislation with extraterritorial effects. Third is the treatment of multinational enterprises. In his opinion, their legal status as customary international economic law is controversial at best. ${ }^{56}$

Zamora draws only a few conclusions on the legal norms of customary international economic law, other than that their recognition is limited ${ }^{57}$ The first is their passive character. They are consequence of the rule of economic sovereignty, meaning that states are free to, for example, expropriate from foreigners, restrict commerce or regulate their own currency. The second is their vagueness. Such expressions as "appropriate compensation" lack precision and their meaning depends largely on interpretation. This fact undermines predictability but enhances broad acceptance. The third is that

\footnotetext{
${ }^{47}$ Texaco Overseas Petroleum Company / California Asiatic Oil Company v. Government of the Libyan Arab Republic, (1978) 17 International Law Materials 1, 30.

${ }^{48}$ See footnote 35.

${ }^{49}$ Zamora (n 38) 23-25. See also AA Akinsaya, The Expropriation of Multinational Property in the Third World, (New York 1980).

${ }^{50}$ Schwarzenberger (n 30) 49.

${ }^{51}$ I Seidl-Hohenveldern, International Economic 'Soft Law”, (1979) II Recueil de Cours, $163,218$.

52 Zamora (n 38) 27.

${ }^{53}$ AA D'Amato, The Concept of Custom in International Law, (1971) 131.

${ }^{54}$ RW Edwards Jr., International Monetary Collaboration, (1985), 647-654.

${ }^{55}$ FA Mann, The Legal Aspects of Money (1982) 483-484.

${ }^{56}$ S. Zamora (n 38) 31-33.

${ }^{57}$ Zamora (n 38) 34-35.
} 
they apply to extreme economic situations. Expropriation or counterfeiting currency is not normal and common economic transactions.

Zamora notes that there are almost no cases decided based on customary international economic law by either the International Court of Justice or by US courts (with the exception of lex mercatoria). Moreover there are not many decisions based on customary law in general, even though customary law gained much attention of scholars. ${ }^{58}$

The fact that international economic law becomes more complex and detailed further limits the impact of vague customary law. Vagueness, difficulties with proving and over-dependence on scholarly opinions result in the limited utility of customary international economic law in litigation. It may be more relevant on political level - in negotiations between states. ${ }^{59}$

\section{LEX MERCATORIA AS A SOURCE OF INTERNATIONAL ECONOMIC LAW}

As mentioned in part 1 of this article, opinions on the definition and content of international economic law vary significantly. The main difference is whether or not to include private law and in particular lex mercatoria. As has been showed above, the concept that international economic law is something more than simply a part of public international law presently dominates. For this reason it is important to determine what lex mercatoria really is.

Classic lex mercatoria was a merchant law in medieval Europe. ${ }^{60}$ It lost its significance with the development of national laws, but regained popularity in the $20^{\text {th }}$ century due to the huge increase in international trade and the need to find law not connected to any particular national legal system. Contemporary lex mercatoria is usually called the new lex mercatoria ${ }^{61}$ or sometimes even the new new lex mercatoria ${ }^{62}$, to emphasise its evolution and progress.

Similarly to the concept of international economic law, there is no consensus among academics as to the definition and extent of lex mercatoria.

Some authors consider lex mercatoria as a system of law. According to Gücer it is an international law system applied by international merchants based on commercial rules and principles ${ }^{63}$. The new lex mercatoria on the other hand is understood as a legal system comprising commercial rules and principles, model laws, general terms and conditions, general principles and

\footnotetext{
${ }^{58}$ Zamora (n 38) 36-39.

${ }^{59}$ Zamora (n 38) 40-41.

${ }^{60}$ O Volckart, A Mangels, 'Are the Roots of the Modern Lex Mercatoria Really Medieval?' (1999) 65(3) Southern Economic Journal 427, 435 ff.; LE Trakman, The Evolution of the Law Merchant: Our Commercial Heritage (1980) 12(2) Journal of Maritime Law and Commerce 1, 4.

${ }^{61}$ E.g. AM López Rodríguez, 'Lex Mercatoria' (2002) RETTID 46, 47.

${ }^{62}$ Y Fortier, 'The New New Lex Mercatoria, or Back to the Future' (2001) 17(2) Arbitration International 121, 125.

${ }^{63}$ S. Gücer, 'Lex Mercatoria in International Arbitration' (2009) 1 Ankara Bar Review 30, 33.
} 
international arbitration. ${ }^{64}$ In the view of Selden, lex mercatoria is a uniform system of law to regulate international commercial transactions, avoiding the vagaries of differing national systems. ${ }^{65}$ Another proposition is that it is a body of rules, different in origin and content, created by the trading community to serve the needs of international trade. ${ }^{66}$

According to the autonomist concept the lex mercatoria has got an autonomous character, independent from any national system of law. Hence, it is "a set of general principles, and customary rules spontaneously referred to or elaborated in the framework of international trade, without reference to a particular national system of law." 67 From a positivist approach the lex mercatoria is defined as a body of rules, transnational in their origin, but which only exists by virtue of state laws, which give them effect.

There are, however, also opinions that the lex mercatoria does not constitute a system of law, since it is incomplete and imprecise. Or that it is not binding, since it has not been adopted by any state and therefore it is not law at all. ${ }^{68}$

The opponents of the recognition of lex mercatoria as law emphasise its lack of legitimacy, originating in the state authority ${ }^{69}$, along with its incompleteness, vagueness and incoherence ${ }^{70}$. There are serious controversies surrounding the exact content of the lex mercatoria. Attempts to make it precise would require enormous research work and would still be vulnerable to the accusations of subjectivity. ${ }^{71}$. In consequence, arbitration flexibility could lead to absolute unpredictability of a dispute and excessive discretional power of neutrals.

International private law experts discredit lex mercatoria, while researchers and practitioners of trade law and arbitration law promote it. Arguments against it refer not only to the lack of a binding character, but also the lack of democratic legitimacy and constitutional warranties. ${ }^{72}$ Arguments in favour of lex mercatoria are based on empirical evidence - actual resolution of disputes on this basis. Pragmatists notice that lex mercatoria's existence is supported by the practice of international commercial arbitration away from scholar debate. It is founded on parties' autonomy, good faith and

\footnotetext{
${ }^{64}$ Gü̧еr (n 63) 35.

${ }^{65}$ BS Selden, 'Lex Mercatoria in European and U.S. Trade Practice: Time to Take a Closer Look' (1995) 2(1) Annual Survey of International and Comparative Law 111, 112.

${ }^{66}$ López Rodríguez (n 61) 47.

${ }^{67}$ B. Goldman, 'The Applicable Law: General Principles of Law - the Lex Mercatoria' in J Lew (ed), Contemporary Problems in International Arbitration (1987), 116.

${ }^{68}$ López Rodríguez (n 61) 49; G Baron, 'Do the UNIDROIT Principles of International Commercial Contracts form a new lex mercatoria?, 'http://www.cisg.law.pace.edu/cisg/biblio/baron.html> accessed 28 January 2015 r., 5; FA Mann, 'England rejects Delocalised Contracts and Arbitration' (1984) 33(1) International and Comparative Law Quarterly,193, 193-198.

${ }^{69}$ E.g. K Highet, 'The Enigma of the Lex Mercatoria' (1989) 63 Tulane Law Review 431, $613 \mathrm{ff}$.

${ }^{70}$ E.g. O Chukwumerije, Choice of Law in Commercial Arbitration (Westport 1994), s. 112; M Mustill, S Boyd, Commercial Arbitration, (1989) 81.

${ }^{71}$ Baron (n 68) 5.

${ }^{72}$ R. Michaels, 'The True Lex Mercatoria: Law Beyond the State' (2007) 14(2) Indiana Journal of Global Legal Studies 447, 448, 451-452.
} 
arbitration ${ }^{73}$. Private party's actions should be taken into account in research of contemporary legal tendencies in international trade. They play main roles in this area. And they have a right to choose law which shall apply to their contracts. ${ }^{74}$.

The consequence of the dispute about the definition of the lex mercatoria is a dispute about its sources. In an autonomist approach, they include general principles of law and international trade usages ${ }^{75}$. In a positivist approach, they include trade usages codified in, for example, ICC documents (e.g., INCOTERMS).

Ole Lando supports a broad understanding of the sources of the lex mercatoria, including public international law, uniform laws, general principles of law, rules of international organizations, customs, standard form contracts and arbitral awards ${ }^{76}$. Goode claims, that the lex mercatoria should be considered as customary international law ${ }^{77}$. Baron presents a view that it only encompasses model laws and recommendations from international organizations ${ }^{78}$. Godlamn recognizes as the lex mercatoria, only unwritten norms ${ }^{79}$. Goode ${ }^{80}$ on the other hand only recognises trade usages and general principles of law, which is an unwritten part of transnational commercial law. Lex mercatoria shares with the general principles of law some common principles, such as pacta sunt servanda or rebus sic stantibus ${ }^{81}$. Volckart and Mangels claim that the main source of the lex mercatoria are trade rules codified by professional non-governmental organizations, such as INCOTERMS ${ }^{82}$. It happens that arbitration courts confirm in their awards, that the Vienna Convention on international sale of goods forms a part of the lex mercatoria ${ }^{83}$. In the view of Michaels, the lex mercatoria has never been fully anational law. It always consisted of both municipal laws and other ${ }^{84}$. Business practice is that merchants choose between municipal and other norms and also between state and arbitration courts ${ }^{85}$. There are also opinions that, in the development of the lex mercatoria, one cannot underestimate the role of the neutrals, who happen to create law, which they subsequently apply $^{86}$. In every case the lex mercatoria is mostly material law. Only

${ }^{73}$ F. Dasser, Internationale Schiedsgerichte und lex mercatoria (1989) 46.

${ }^{74}$ Selden (n 65) 111.

${ }^{75}$ Goldman (n 67) 114.

${ }^{76}$ O Lando, 'The Lex Mercatoria and International Commercial Arbitration' (1985) 34(4) ICLQ 747, 748-752.

${ }^{77} \mathrm{R}$ Goode, 'Usage and Its Reception in Transnational Commercial Law' (1997) 46(1) International \& Comparative Law Quarterly 1, 4.

${ }^{78}$ Baron (n 68) 4.

${ }^{79}$ Goldman (n 67) 113.

${ }^{80}$ Goode (n 77) 4.

${ }^{81}$ AFM Maniruzzaman, 'The Lex Mercatoria and International Contracts: A Challenge for International Commercial Arbitration?' (1999) 14(3) American University International Law Review 657, 712; Gücer (n 63) 35.

${ }^{82}$ Volckart, Mangels (n 60) 430.

83 See MT Davidson, 'The Lex Mercatoria in Transnational Arbitration: An Analytical Survey of the 2001 Kluwer International Arbitration Database' <http://www.cisg.law.pace.edu/cisg/biblio/davidson.html > accessed 6 January 2015, 2.

${ }^{84}$ Michaels (n 72) $453 \mathrm{ff}$.

${ }^{85}$ Michaels (n 72) 459.

${ }^{86}$ E.g. M. Mustill, 'The New Lex Mercatoria: The First Twenty-five Years' in M Bos, I Brownlie (eds), Liber Amicorum for Lord Wilberforce (1987) 161; Lando (n 76) 747. 
exceptionally does it include the norms of the procedural law, such as due process, right to counsel or right to present evidence ${ }^{87}$.

In the positivist approach among sources of the lex mercatoria one usually mentions UNIDROIT Priniciples of International Commercial Contracts of 1994 and the European Principles of Contract Law ("EPCL") of 1999. UNIDROIT Principles apply only to transnational commercial agreements, while the EPCL also applies to municipal and non-commercial agreements. They are predictable, coherent and complete, therefore do not possess traditional weaknesses of the sources of the lex mercatoria "88. There are authors, however, who present a radical view that only this part of the above mentioned regulations constitutes the lex mercatoria, which mirrors actual practice in international trade ${ }^{89}$.

The UNIDROIT Principles are described as a "milestone" in the development of the lex mercatoria ${ }^{90}$. Already the Preamble to the Principles directly uses the notion lex mercatoria, stating that the Principles may apply among other situations when the parties choose lex mercatoria as the law governing their agreement. On the one hand the Principles suit the characteristics of the sources of the lex mercatoria: they are transnational, based on common grounds and mirror the trade usages. On the other hand they suit the quality characteristics of the system of law: completeness and precision. They do not, however, meet the condition of being made by states, if to someone it is a condition of being considered as law ${ }^{91}$.

\section{CONCLUSION}

The main problem with surveying customary international economic law is that there is no universally accepted understanding of the term international economic law. On the contrary, there are huge differences in this regard, ranging from classifying it as a part of public international law to a broad area of law, covering parts of international, municipal and other law, distinguished by the object of regulation - international economic relations of public and private nature. This second concept is nowadays dominant among scholars.

Customs play a surprisingly small role in international economic law, which is generally dominated by treaty law since the establishment of the Bretton Woods institutions. There are only a few examples of it and still some of them are controversial. Generally states are free to regulate the status of foreign entrepreneurs in their territory, including such issues like expropriation or restrictions to commerce. But there are no such customs as freedom of trade or most-favoured-nation treatment. The status of the UN General Assembly resolutions pertaining to the so called New International Economic Order is questioned by the developed states. There is some

\footnotetext{
${ }^{87}$ Davidson (n 83) 7.

${ }^{88}$ López Rodríguez (n 61) 51.

${ }^{89} \mathrm{KP}$ Berger, 'The relationship between the Unidroit Principles of International Commercial Contracts and the new lex mercatoria' (2000) 5(1) Uniform Law Review 153, 169.

${ }^{90}$ Maniruzzaman (n 81) 659, 670.

${ }^{91}$ Baron (n 68) 8-9.
} 
recognition of the trade usages, but they necessarily refer at least partly if not exclusively to the lex mercatoria - a term which needs explanation.

The notion of lex mercatoria has been known since medieval times, but it has evolved and changed. There is a great disagreement between scholars as to what is to be presently understood by the lex mercatoria, what it consists of, whether it is binding or if it is law at all. What is certain is that it is based on customs. Therefore one should recognize it as a part of customary international law, provided one recognizes it as law in the first place.

\section{References}

Abbott KW, 'International Economic Law: Implications for Scholarship' (1996) 17(2) University of Pennsylvania Journal of International Economic Law 505.

Akinsaya AA, The Expropriation of Multinational Property in the Third World (1980).

Atik J, 'Uncorking International Trade, filling the cup of International Economic Law' (1999-2000) 15 American Journal of International Law Review 1231.

\begin{tabular}{clll}
\multicolumn{2}{c}{ Baron G, 'Do the UNIDROIT Principles of International Commercial } \\
Contracts form a new lex mercatoria?,
\end{tabular} 'http://www.cisg.law.pace.edu/cisg/biblio/baron.html

Bello JH, Holmerz AF, 'After the Cold War: Whither International Economic Law?' (1991) 32(2) Harvard International Law Journal 323.

Berger KP, 'The relationship between the Unidroit Principles of International Commercial Contracts and the new lex mercatoria' (2000) 5(1) Uniform Law Review 153.

Białocerkiewicz J, Powstanie i rozwój prawa międzynarodowego gospodarczego (1987).

Chukwumerije O, Choice of Law in Commercial Arbitration (Westport 1994).

D'Amato AA, The Concept of Custom in International Law (1971).

Dasser F, Internationale Schiedsgerichte und lex mercatoria (1989).

Edwards Jr. RW, International Monetary Collaboration (1985).

Ellis ME, 'The New International Economic Order and General Assembly Resolutions: the Debate over the Legal Effects of General Assembly Resolution Revisited' (1985) 15 California Western International Law Journal 647.

Fortier Y, 'The New New Lex Mercatoria, or Back to the Future' (2001) 17(2) Arbitration International 121.

Gilas J, Prawo międzynarodowe gospodarcze (1998).

Goldman B, 'The Applicable Law: General Principles of Law - the

Lex Mercatoria' in

Goode R, 'Usage and Its Reception in Transnational Commercial Law' (1997) 46(1) International \& Comparative Law Quarterly 1.

Gücer S, 'Lex Mercatoria in International Arbitration' (2009) 1 Ankara Bar Review 30. 

Review 431.

Highet K, 'The Enigma of the Lex Mercatoria' (1989) 63 Tulane Law

Jackson JH, 'International Economic Law: Reflections on the "Boilerroom" of International Relations' (1995) 10 American University Journal of International Law and Policy 595.

Lando $\mathrm{O}$, 'The Lex Mercatoria and International Commercial Arbitration' (1985) 34(4) ICLQ 747.

Lankosz K, Kuźniak B, 'Stosunki międzynarodowe - przedmiot i metoda nauczania <http://www.pism.pl/pdf/K.Lankosz-B.Kuzniak.pdf> .

Lew J (ed), Contemporary Problems in International Arbitration (1987) 116.

Lowenfeld AF, International Economic Law (2008).

López Rodríguez AM, 'Lex Mercatoria' (2002) RETTID 46.

Maniruzzaman AFM, 'The Lex Mercatoria and International Contracts: A Challenge for International Commercial Arbitration?' (1999) 14(3) American University International Law Review 657.

Mann FA, 'England rejects Delocalised Contracts and Arbitration' (1984) 33(1) International and Comparative Law Quarterly 193.

Mann FA, The Legal Aspects of Money (1982) .

McRae DM, 'The Contribution of International Trade Law to the Development of International Law' (1996) 1 Recueil des Cours de l'Academie de Droit International 99.

Michaels R, 'The True Lex Mercatoria: Law Beyond the State' (2007) 14(2) Indiana Journal of Global Legal Studies 447.

Mortelmans K, 'The Interdependence of International, European and National Economic Law: The European Community Example' in PV Dijk Restructuring the international economic order: the role for law and lawyers (1986) 14.

Mustill M, Boyd S, Commercial Arbitration (1989).

Mustill M, 'The New Lex Mercatoria: The First Twenty-five Years' in M Bos, I Brownlie (eds), Liber Amicorum for Lord Wilberforce (1987) 161.

Petersmann E-U, 'International Economic Theory and International Economic Law: On the Tasks of a Legal Theory of International Economic Order' in RStJ MacDonald, DM Johnston (eds) The Structure and Process of International Law: Essays in Legal Philosophy Doctrine and Theory (1983) 251 .

Picker CB, Bunn ID, Arner DW (eds), International Economic Law. The State and Future of the Discipline (2008).

Qureshi AH, Ziegler A, International Economic Law (2011).

Schwarzenberger G, The Principles and Standards of International Economic Law (1966) 117 Recueil des Cours 1.

Schwarzenberger G, 'The Province and Standards of International Economic Law' (1984) 2 International Law Quarterly 402.

Seidl-Hohenveldern I, International Economic Law (1999).

Selden BS, 'Lex Mercatoria in European and U.S. Trade Practice: Time to Take a Closer Look' (1995) 2(1) Annual Survey of International and Comparative Law 111. 
Trakman LA, The Evolution of the Law Merchant: Our Commercial Heritage (1980) 12(2) Journal of Maritime Law and Commerce 1.

VerLoren van Themaat P, The Changing Structure of International Economic Law (Hague 1981).

Villiger ME, Customary International Law and Treaties (1985).

Volckart O, Mangels A, 'Are the Roots of the Modern Lex Mercatoria Really Medieval?’ (1999) 65(3) Southern Economic Journal 427.

Wasilewski T, 'Prawo międzynarodowe publiczne, międzynarodowe prawo gospodarcze a europejskie prawo wspólnotowe - aspekt komparatystyczny' (2005) 3 Studia Europejskie 31.

Wasilewski T, Stosunek wzajemny: porzadek międzynarodowy, prawo międzynarodowe, europejskie prawo wspólnotowe, prawo krajowe (2004)

Zamora S, 'International Economic Law', (1996) 17(1) University of Pennsylvania Journal of International Economic Law 63.

Zamora S, 'Is There Customary International Economic Law?' (1989) 32 German Yearbook of International Law 9.

Ziemblicki B, 'Współczesne rozumienie pojęcia międzynarodowego prawa gospodarczego’ (2014) 197(1) Studia Prawnicze PAN 181. 